\title{
An Ecocritical Reading: Demonizing the Nature Found In Batang's Folktale
}

\author{
Dwi Ario Fajar ${ }^{1}$ \\ Universitas Pekalongan, Indonesia ${ }^{1}$ \\ \{dwiariof@gmail.com ${ }^{1}$ \}
}

\begin{abstract}
In Indonesia, Folklore has been part of life, especially folktale which relates to the history of naming places. The issues of the environment become the new trend for literature but not Indonesian folktale and legend. The objective of the study aims to analyze an ecocritical reading of demonizing the nature found in Batang's Folktale. This study uses the descriptive qualitative method and ecocriticism theory. It reveals the hostility between nature and culture, humans and demons. Surprisingly the image of nature symbolizes as demons.
\end{abstract}

Keywords: Ecocriticism, Folktale, Nature

\section{INTRODUCTION}

There is a close relationship between literature and life. The social function of literature is how it involves in the midst of people's lives. The relationship between literature and society cannot be separated. Literature affects society and conversely, society also influences the creation of literary works.

The link between literature and society makes the influence of certain mindsets in society. Literature forms the values that will be considered by the community as the right and canon. So that literature is actually a tool for forming character, morals, and general truths of society.

The literary has influence in society. Literature is considered to be a tool in inserting an ideology. In the long history, literature is considered and used by several rulers to instill its power hegemony. For example in the case of Boris Pasternak, at first Pasternak's work entitled "Doctor Zhivago" could be freely read but later banned because he criticized the Soviet Union's government sharply through literature.

In Indonesia, a literary battle also occurs. In the Indonesian New Order era, literary works by authors who were considered communist sympathizers were forbidden to be read, although the content of the stories did not related to communism. The Indonesian government at that time assumed that literary works carried communist ideological messages brought by certain authors.

This example assures us that literature is not just a dead text. Literature lives and brings great change because the contents of certain values and ideologies are deliberately put into literary works. Even though most people think that literature is only a fictional item that cannot be justified. But from the explanation, above we know that fictional literature gives rise to imagination whose has enormous effects. The fiction and fictional literary debate has been explained by Eagleton in a comprehensive manner. Ranging from literary works as 
imaginative writing, the difference between facts and fiction, the understanding of literature in the 17th century in England to the totality of the text system brought by Formalism Russia[1].

Then what about the folktale which is part of folklore? Folklore in the form of oral tradition is very vulnerable to extinction. Not well documented is one factor of the loss of oral folklore [2]. At present, there are many assumptions that folklore is part of local wisdom. Local wisdom is considered a noble value from the ancestors. But are these values not intentional in inserting a particular ideology?

Folk stories are oral literary works delivered from generation to generation. Indonesia has much folklore. One of them is the story behind the realization of a place name or toponymy. Unfortunately, the study of literature on the environment in Indonesia is still limited because it relates to the limited ecological perspective of literature [3].

This article will reveal whether there are deviations and power relations that take refuge behind local wisdom such as folktale and legend. In addition, this article will also discuss how the legend of the Batang is criticized in terms of ecocriticism.

\section{METHODOLOGY}

This study uses descriptive qualitative research. The material object of this study is the Legend of Batang. It is taken from the compilation of Legenda, Mitos \& Sejarah, 35 Kota di Jawa Tengah, Hadi Priyatno[4]. This formal object that is used in this study is ecocriticism Ecocriticism observes the interconnection between nature and culture, especially the cultural artifacts of literature and language [5]. Ecocriticism is the study of the relationship between literature and environment conducted in a spirit of commitment to environmentalist praxis [6].

\section{DISCUSSION}

\section{a. The Legend of Batang}

Batang is one of regency in Central Java Province in Indonesia. Based on the story, the name of "Batang" comes from when Adipati Dipokusuma got a mandate from the King of Mataram to do clearing land in Alas Roban. Alas Roban was a sacred forest. No one has the bravery to go there. But Adipati Dipokusumo was not brave enough to deny the king's mandate. Actually, the king asked him to clear the land because Alas Roban was the right place for logistic of Mataram army. Adipati Dipokusumo then tried to find a way by meditation. From his meditation, he got guidance from God. From his meditation, he must go to Ki Ageng Cempaluk. After meeting with Ki Ageng Cempaluk, Ki Ageng Cempaluk asked his son Joko Bahu or Bahurekso to help Adipati Dipokusumo. Bahurekso waited for Kliwon Thursday night. Kliwon Thursday night is the sacred night for Javanese. Bahurekso waited for that time because Alas Roban was a place which many demons lived there. When Bahurekso and his team wanted to work clearing land, there was an incident. Many of his team members were sick in the morning and died later on. Then, Bahurekso found out that the causes of his team members dead were the attack of demons. The demons were angry because they did not want Bahurekso and his teams cut all the trees in the Alas Roban forest. Bahurekso fought with the demons king of Alas Roban demon named Dadung Awuk. Finally, the Dadung Awuk was defeated. Dadung Awuk asked Bahurekso should give him the produce of farming and estate. After Bahuresko finished his job, he asked his team to convert the forest to farming. It would help the logistic of Mataram for attacking to Batavia. Then Bahurekso made the dam for watering the farm. But he got trouble from White Eel demon. White Eel demon disturbed the irrigation by putting the very big log to the drainage. 
Finally, the Waite Eel demon can be defeated. Then Batang the name of this regency became prosperous regency because of benefit from the farming and estate. The name of Batang comes from the word "ngembat watang" which means lifting the log. The log was from White Eel demon.

\section{b. Nature versus Culture}

In the Batang folklore, Alas Roban was converted into a food barn for Mataram troops when they were going against Batavia, from forests to agriculture and plantations. From here we see a change in the function of the land. It seems like nothing had happened. But when we look deeper into the ecocriticism approach, we will see a natural imbalance. Forests that were previously described as sacred or haunted forests turned into agricultural land.

The change in the function of this land is a battle between nature and culture. Forests are forced to change functions for human needs without a preservation process. Humans only think of human needs without regard to the forest. Forests are considered as inanimate and passive objects. The dichotomous mindset produces binarism which is meticulously modeled by Claude Levi-Strauss [7].

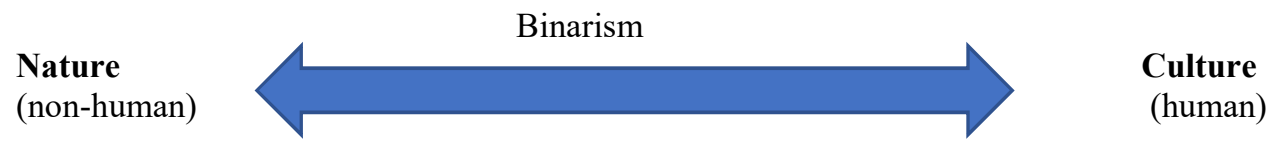

Although in the ecocriticism view there have been changes in the paradigms of nature, nurture and culture, in this story no nurture was found. What happened was to give compensation to the landowner, the Demon. In the story of the king of the demon was given compensation from the benefit of processing agricultural land. So this cannot be said that there is nurture. If there was nurture in the story, the demons would not be disturbed from their place of residence. It indicates that there is no natural harmony.

\section{c. Demonizing the Nature}

If it is analyzed deeper there are several representations that are covered by the story. For example, the nature of the story is represented by demons why? We will see the demon role in the story of the Batang legend. When Bahurekso cleared the land, the demons always fought Bahurekso. It starts from demon troops, Demon King and White Eel Demon. This means that there is resistance in transforming forests into agricultural land. Forest and nature refuse through the demon-representation that confronts Bahurekso. So that nature and forest are considered as demons. Everyone understands that demons are the negative things. So that unconsciously the stories told for generations have a negative impact on nature. It is implied that we may do destruction against nature. Nature that we should guard is represented as a demon. "Sacred forest" is no longer sacred because of human needs. Human needs are everything. Human need oriented is formed. It will neglect all the impact.

In the story, Bahurekso got a disturbance from the White Eel demon. At that time he made irrigation for agriculture. But the waterways are disturbed because there are large tree $\log$ covering the river. Again, what is blamed is a demon. This seems to be a scapegoat. Demon and nature are blamed when human need is disturbed.

If an ideology like this includes in a legend that is part of local wisdom then what happens is environmental damage. Our assumption if this story has been followed in generations, we can feel the impact now. As quoted by radarsemarang.com, writing the news entitled "Forests 
in Central Java Threatened to Damage" can we make the experience that local wisdom must be well taught [8].

\section{d. Native Life Blending with Nature (Nurture vs Culture)}

From ecological criticism, the representation of the demon is native that lives in the midst of nature. We can interpret the native people representation if we see the other side of the demon attitude towards Bahurekso. The demon is always opposed to Bahurekso's actions. Bahurekso who cleared Alas Roban made demon's life disturbed. This means that the demon lives in harmony with nature. They have become one with nature. Like inland tribes. Even from this story demon representation is a representation of the inner tribes that have lived in harmony with nature. Just imagine when a resident who has lived a long time in nature then there is a group of foreigners who suddenly damage their occupancy. It must be their basic instinct to fight destroyer.

The colonization of newcomers or foreigners into a new world creates clashes between natives and foreigners. We do not call the native as the xenophobia but it is strong resistance among native people. The rest of this legend contains a description of the colonization of foreigners against native residents represented by Bahurekso and the Demon.

\section{CONCLUSION}

Local wisdom must indeed be maintained and conserved for generations because local wisdom is an ancestral heritage. Local wisdom must also be understood and criticized. The litreary criticism can be implemented toward folklore, folktale, legend and myth. This effort to criticize folktale as local wisdom is intended to prevent wrong understanding in society. Educating the environmental issues in our folklore must always be considered. This concerns ecological education for the next generation.

\section{References}

[1] T. Eagleton, and Drew Milne, eds. Marxist Literary Theory: A Reader. Wiley-Blackwell, 1996.

[2] D. A. Fajar, "Pekalongan Folklore Dewi Lanjarfor Teaching Learning: A Feminist Study." English Language and Literature International Conference (ELLiC) Proceedings. Vol. 1. 2017.

[3] N. Dewi, "Manusia dan Lingkungan dalam Cerpen Indonesia Kontemporer: Analisis Ekokritik Cerpen Pilihan Kompas." Litera 14.2 (2015).

[4] H. Priyanto, (2015) Legenda, Mitos \& Sejarah 35 Kota Di Jawa Tengah. Semarang: Lembaga Pelestari Seni Ukir, Batik dan Tenun Jepara

[5] D. A. Fajar, "ECO-LITERACY THROUGH ECOCRITICISM IN PEKALONGAN FOLKLORE." FACULTY OF LANGUAGES AND ARTS YOGYAKARTA STATE UNIVERSITY (2017): 73.

[6] C. M. Christensen, et al. (2008) Disrupting Class: How disruptive innovation will change the way the world learns. New York: McGraw Hill

[7] S. Harsono, "Ekokritik: Kritik Sastra Berwawasan Lingkungan." Kajian Sastra 32.1 (2012): 31-50.

[8] http://radarsemarang.com/2017/04/01/hutan-di-jateng-terancam-rusak/ 